\title{
An Analysis of Code-Mixing and Code-Switching in EFL Teaching of Cross Cultural Communication Context
}

\author{
Martin Kustati \\ English Department, Faculty of Islamic Education and Teacher Training \\ IAIN IB Padang, Indonesia \\ E-mail: martinkustati@yahoo.com \\ DOI: http://dx.doi.org/10.15548/jt.v21i3.101
}

\begin{abstract}
The objective of the paper is to determine types of code-mixing and code-switching made by teachers and students in EFL cross cultural communication class and to identify reasons for the emergence of codeswitching and mixing in the classroom. The data was obtained through observation and in-depth interviews of the second year students of undergraduate program of English in Tarbiyah Faculty, IAIN IB Padang. The finding showed that tag-switching, intra-sentential, inter-sentential, and intra-word were commonly used by EFL teachers and students in classroom. It was also found that the teachers used code-mixing and switching in the process of clarifying certain issues to make them more comprehensible to students. Teachers also do these kinds of switching during their attempt to promote relationship with students, to switch the topic, and to persuade or motivate students to be more engaged in learning English. Meanwhile, the students mix and switch their language to overcome their lack of knowledge of English. It is expected that this study provided empirical evidence to advise on their optimal uses in EFL teaching of State Institute for Islamic Studies.
\end{abstract}

Keywords: code-mixing, code-switching, EFL teaching, motivational functions, and cross cultural communication.

\section{INTRODUCTION}

A number of teaching language phenomena in EFL contexts have been explored in different societies and nationalities resulting in several sociological and psychological understanding of their contributions to either language development or educational program. Code-mixing and switching have been considered as rule-governed behavior and as a communication strategy as well. They serve important communicative and cognitive functions. However, some social stigmas have been attributed to this mode of communication. For example, some ELT experts claim that speakers who use mixing and switching are actually not competent English speakers. This is actually not very true given that code mixing and switching are not only a matter of mixing of two particular languages, speakers are also required to acquire sophisticated knowledge of both languages and cross cultural communication norms. Therefore, those engaged in code mixing and switching are acquire both language and cross-cultural communication norms. Understanding cross cultural norms of certain communities is important to help one avoids misperception in producing certain expressions. This is because language is a system, by which people communicate to one another. Therefore, literature shows that speakers who use codemixing show a higher level of linguistic competence since it necessitates simultaneous processing of the rules of both languages (Auer, 1996). The ability to engage in code-mixing and switching indicate that speakers acquire a high level of proficient in two languages (Butzkamm, 1998).

As the paper deals with classroom discourse in which English as a Foreign Language (EFL) is taught to multi-ethnic students who study at the undergraduate program of English at Tarbiyah Faculty, IAIN Imam Bonjol Padang. These students have to struggle to have adequate competence in English. Majority of the students are Minangkabaunese living around the West Sumatra province, while others are from 
neighborhood provinces. In some ELT teachings, Indonesian was sometimes used during the instruction for the clarity of teaching materials. Some students were observed to use their natives such as Bataknese, Minangkabaunese, and Javanese during discussion sessions. As most English lecturers' efforts to develop students communicative competence through various tasks and activities, students have been noted to mix and switch, and these may have been responded differently among the lecturers.

Current analysis of code mixing and switching in English undergraduate program at Tarbiyah Faculty of State Institute for Islamic Studies 'Imam Bonjol' Padang was directed to answer the following questions: (1). What types of code-mixing and switching are frequently used in EFL teaching of cross cultural communication?; and (2). What are the motivational reasons to use code mixing and switching in the classroom? Why do code mixing and switching occur?.

\section{METHOD}

A classroom observation was done to 33 students in undergraduate program of English at Faculty of Islamic Education and Teacher Training, IAIN Imam Bonjol Padang academic year 2013/2014. The interview was also carried out to 2 English lecturers and 6 English students to elicit information about why they code-mix and switch in their classroom.

\section{RESEARCH FINDINGS}

Code-Switching and Code-Mixing in EFL Teaching at State Institute for Islamic Studies.

The data in this study are derived from observation checklist. The observation sessions have been conducted in one semester in academic year 2013/2014 in undergraduate program of English at Tarbiyah Faculty IAIN Imam Bonjol Padang. 
Tabel 1

Summary of Observation of Using Code-Mixing and Switching

\begin{tabular}{|c|c|c|}
\hline $\begin{array}{l}\text { Aspects/ } \\
\text { Indicator }\end{array}$ & Contexts & Interaction \\
\hline \multirow[t]{3}{*}{$\begin{array}{l}\text { Intra-Sentential } \\
\text { Switching / Code } \\
\text { Mixing } \\
\text { Mixes and } \\
\text { switches the } \\
\text { language occurs } \\
\text { within a phrase, a } \\
\text { clause or a } \\
\text { sentence. }\end{array}$} & $\begin{array}{lr}\begin{array}{l}\text { When second } \\
\text { students }\end{array} \text { were being } \\
\text { taught }\end{array}$ & $\begin{array}{l}\text { T: We have discussed that language learning } \\
\text { strategy refers to specific behaviors or thought } \\
\text { processes that learners use to enhance their } \\
\text { learning } \\
\text { S: I think 'ndak mangarati do bu!', I have } \\
\text { asked my friends. } \\
\text { T: Alright, ... let's review our last week } \\
\text { material. Who still remember 'tentang } \\
\text { pengertian strategi belajar bahasa?'. Probably } \\
\text { Agus, can you explain?. }\end{array}$ \\
\hline & $\begin{array}{l}\text { Students were asked to } \\
\text { discuss new topic } \\
\text { (Taxonomy of Language } \\
\text { Learning Strategies) in a } \\
\text { group (2). }\end{array}$ & $\begin{array}{l}\text { T: Discuss the given topic in your groups, } \\
\text { then, give example in your learning contexts } \\
\text { and report it in for the whole class. } \\
\text { S: Wow Miss.. 'banyak bana mah buk!' ، } \\
\text { difficult!. } \\
\text { T: (Smiling)... Okay, just take an example for } \\
\text { each. }\end{array}$ \\
\hline & $\begin{array}{l}\text { When the time came for } \\
\text { presentation of the } \\
\text { report, the class was a } \\
\text { little crowded ( } 3 \text { ). }\end{array}$ & $\begin{array}{l}\text { T: Now, which group will present first? } \\
\text { S: Difficult Miss..' alun siap do buk!' 'We are } \\
\text { not ready, buk!' .........................(a) } \\
\text { T: Then I call group one. Who are the } \\
\text { members? } \\
\text { S: Oh my god.. 'Seng aku ora iso!' (Javanese-- } \\
\text { - 'Oh my God, I can't do it' .................(b) } \\
\text { S: Do you know....'a tuh nandi keceak an ibuk } \\
\text { tadi?' (asking to the neighbor). 'What does } \\
\text { Miss. Martin say?'. } \\
\text { T: who will be the moderator?.... (c) } \\
\text { T: That's a god presentation of group one. Now } \\
\text { please ask them. } \\
\text { S: 'nda mangarti au aha na idokon ni apak I } \\
\text { dah' (Batak --- 'I don't understand him'!) } \\
\text { T: Well, Ori, what's the title of that research? }\end{array}$ \\
\hline $\begin{array}{l}\text { Intra-word code } \\
\text { Mixing/switching } \\
\text { Mixes and } \\
\text { switches the } \\
\text { language within }\end{array}$ & $\begin{array}{lrr}\begin{array}{l}\text { When } \\
\text { students }\end{array} \begin{array}{r}\text { second } \\
\text { were }\end{array} \begin{array}{r}\text { year } \\
\text { being }\end{array} \\
\text { taught } & \text { Language } \\
\text { Learning } & \text { Strategy } \\
\text { Subject, Intra-word code- } \\
\text { mixing and } & \text { switching }\end{array}$ & $\begin{array}{l}\text { T: By the way, hari ini who does not come? } \\
\text { S: Rina Miss... She mengikuti poetry reading } \\
\text { competation. }\end{array}$ \\
\hline
\end{tabular}




\begin{tabular}{|c|c|c|}
\hline the words. & $\begin{array}{l}\text { occurred (1) } \\
\text { When there was a student } \\
\text { came late for the class, } \\
\text { intra word code } \\
\text { switching occurred (2) } \\
\text { At the end of the lesson, } \\
\text { the lecturer give } \\
\text { students' homework (3). }\end{array}$ & $\begin{array}{l}\text { S: I am sorry I'm late. } \\
\text { T: Why do you come late? } \\
\text { S: I am hungry and I'makan siang' with my } \\
\text { friend Miss... I am so sorry, Miss. } \\
\text { T: Did you forget the schedule? } \\
\text { S: No, Miss. } \\
\text { (The rest of the class laughed....). } \\
\text { T: Why do we need to understand these } \\
\text { aspects? } \\
\text { S: So that we can train our strategy 'yang } \\
\text { digunakan'.... and you can try them. } \\
\text { T: To make sure, read again page... at home. } \\
\text { T: Please collect your works next week, OK? } \\
\text { S: I think 'Naam' Miss (Arabic--- 'yes') } \\
\text { T: OK, don't forget to write your names! }\end{array}$ \\
\hline $\begin{array}{l}\text { Tag- } \\
\text { switching/mixing } \\
\text { The language } \\
\text { occurs at the } \\
\text { phonological level } \\
\text { (the switching of } \\
\text { either a tag phrase } \\
\text { or a word, or both, } \\
\text { from language-B } \\
\text { to language-A) }\end{array}$ & $\begin{array}{l}\text { When the presentation } \\
\text { session, tag } \\
\text { switching/mixing } \\
\text { occurred (1). }\end{array}$ & $\begin{array}{l}\text { S1: The konsep of language learning strategy } \\
\text { refers to Oxford's theorykan..... } \\
\text { S2: How can that conceptnya } \\
\text { diimplementasikan to enhance our language } \\
\text { learning? }\end{array}$ \\
\hline $\begin{array}{l}\text { Intersentential } \\
\text { code- } \\
\text { mixing/switching } \\
\text { - Mixes and } \\
\text { switches the } \\
\text { language occurs } \\
\text { outside a phrase, } \\
\text { a clause or a } \\
\text { sentence. }\end{array}$ & $\begin{array}{l}\text { When the time came for } \\
\text { presentation of the } \\
\text { report, inter-sententiall } \\
\text { code switching occurred } \\
\text { (1) }\end{array}$ & $\begin{array}{l}\text { T: Are you ready report the result of your } \\
\text { discussion?. } \\
\text { S1: We try Miss...we only present the } \\
\text { example of strategy in our daily life, bukankah } \\
\text { begitu yang harus dilakukan, Miss? }\end{array}$ \\
\hline
\end{tabular}




\section{Intra-Sentential Switching/Mixing}

The data shown in the table 1 indicate that the order of the phrases or sentences is syntactically remained. Each of the examples seems to show a complete sentence. Take sentences in context 1 , for example

- I think 'ndak mangarati do bu!', I have asked my friends"

- Alright, ... let's review our last week material. Who still remember 'tentang pengertian strategi belajar bahasa?'. Probably Agus, can you explain?.

- Wow Miss.. 'banyak bana mah buk!' 'difficult!.

- Difficult Miss..'alun siap do buk!' 'We are not ready, buk!

- Oh my god..'Seng aku ora iso!' (Javanese--- 'Oh my God, I can't do it'

- Do you know....'a tuh nandikeceak an ibuk tadi?' (asking to the neighbor).

- 'nda mangarti au aha na idokon ni apak I dah' (Batak --- 'I don't understand him'!)

The sentences become the subject of intrasentential mixing and switching which are grammatically correct, meaning the grammatical rules of English are maintained. The examples can also show that the use of code mixing and switching can be due to a kind of a language variation found in a society of bilingual or multilingual speakers, in Indonesian for instance, such a combination is now a common place to most Indonesians, since they are bilingual. People in society tend to mix their sentences with whatever 'high-status languages' they know. Such mixing type could be an example to show equivalence constraint regarded as a strategy in social interaction (Appel and Muysken,1987).

\section{Intra-Word Code Switching/Mixing}

Intra-words switching occurs within a word, itself, such as at a morpheme boundary. It can be seen in the following examples:

- By the way, hari ini who does not come?

- Rina Miss...She mengikuti poetry reading competition.
- I am hungry and I'makan siang' with my friend Miss... I am so sorry, Miss.

- S: So that we can train our strategy 'yang digunakan'.... and you can try them.

The examples above indicate that the speakers tend to switch code in a word or phrase as long as the word or phrase does not violate the grammar of either code.

\section{Taq-Switching/Mixing}

Tag switching is where the language occurs at the phonological level (the switching of either a tag phrase or a word, or both, from language- $\mathrm{B}$ to language- $\mathrm{A})$, as in the sentence 1 and 2. This type of tag switching can be seen in the following example:

- The konsep of language learning strategy refers to Oxford's theorykan.....

- How can that conceptnya dimplementasikan to enhance our language learning?.

It is also implied that the words such as conceptnya and theorykan are some of the words in this type that were used. Each of the words above consisted of two codes, English and followed by Indonesian word -nya and kan. The words above added by suffix - nya and kan that come from Indonesian language. In IntraLexical Mixing the two codes have been mixed in a word to complete sentences. The examples are in line with what Ayeomoni (2006) said that kind of translation is a kind of borrowing, where teachers mix target language with native language term "without bothering to translate". Such kind of translation is regarded as a teaching strategy and is made upon the teachers' decision in terms of individual preference.

\section{Intersentential Switching//Mixing}

Inter-sentential switching occurs outside the sentence or the clause level. It can be seen in the example:

- We try Miss...we only present the example of strategy in our daily life, bukankah begitu yang harus dilakukan, Miss?.

The example deals with the interchangeable use of sentences of two 
different languages, the so called code switching, which is an ability to switch from one language to another language. Meanwhile the interchangeable use of different words of different languages within a sentence, the so popularly termed code mixing, is seen as a transfer of a linguistic unit (words, phrases, clauses) from one language into another

\section{Motivational Reasons of Using Code- Switching and Code-Mixing in EFL Teaching at State Institute for Islamic Studies}

The interviews with English lecturers and students at undergraduate program of English showed they have a common perception that code switching and mixing encourage active engagement in the classroom. However, the lecturers are concerned with the fact that students will get used to code switch and mix and reduce the sense of necessity to speak English.

English students admitted that they used Indonesian or mother language due to their inability to communicate in English effectively in fact the fact that they are English students. They argue that they are not be able to engage in extensive communication in English. The challenge is to strike a balance between strategic use of a first language as a scaffolding tool and allowing sufficient practice in a target language. Excessive use of one at the expense of the other in these contexts could increase the possibility of miscommunication between the lecturers and learners.

Meanwhile, English lecturers acknowledged that they use code mixing and switching to switch the topic, to transfer important knowledge to the students, which is impossible to do otherwise, to promote interrelationship between lecturers and students, and to encourage students' participation.

English lecturer also acknowledged that it is easier to transfer materials by switching and mixing the languages, since some students may be incapable of understanding materials if only English is used as classroom language.
Likewise, students argue that they will have a better understanding on the lessons if they are delivered in mixed language.

\section{DISCUSSION}

Some languages either students' first language (local) such as Minangkabaunese, Bataknese, and Javanese, second language (Indonesian), or foreign language (English and Arabic) are used to alternate the mode of communication. This fact suggests that English as an international language has been growing simultaneously with other languages that both students and teacher share during communication (cross cultural communication).

Code-mixing and switching among these languages are natural as the effect of language and culture relationship. Expressing some mother or other language other than target one does not necessarily exclude the students from social or community of students learning English but rather, they symbolize or signal of desires to be accepted in the community. Several signals like identity, equality, and mutual respect were taken place during cross cultural communication. Various codes-mixing and switching found in the normal classroom show the existence of self identity that is the characteristics of the local people where the students are from. These students, individually or collectively, are convinced that they have equal rights and responsibility either as members of the class or as individual citizen who keeps and values the democratic principles in the multi cultural and religious life. Besides, they are also aware of the various or differences shared by the members of global society and each of them should share mutual respects. In sum, enlarging students' vision through internationalism and world civilization of English may take them a step further to the understanding and mastery of English.

It can be said that more code-mixing and code-switching occurred in students which indicate lower mastery of target language. In other words, speakers with a low degree of English language proficiency code mix and 
switch to ensure continuity of conversation. It is obvious from the finding, in which the English lecturers do not encounter major problems communicating in English during teaching. . Whereas majority of students prefer instruction through the use of code-mixing and switching to English per se. This is because they were novice in their English competence and were difficult to communicate in English.

Under the Local and supported by National Curriculum, academic affairs of State Institute for Islamic Studies, Imam Bonjol of Padang, has made tremendous efforts to revise and improve the curriculum for English every year. In undergraduate program of English at Tarbiyah faculty for example, students were provided with some extracurricular activities such as drama, speech, hunting tourists, English club, and seminars. They were also provided with research and paper writing workshops. In these activities, presentations at later stages were sometimes pictured by unexpected view in which most students show the feeling of being oppressed, threaten, shy, etc. Most students experienced very unsafe and humiliated when they are commented, questioned, or criticized.

Motivational reasons for English students in Tarbiyah faculty used code-mixing and switching was to resolve their language barrier and it is in line with what conventional view (see Pagano, 2010). A majority of EFL learners reported that they switched and mixed the language when they cannot find an appropriate word or expression or when the language being used does not have the item or appropriate translations for the vocabulary needed.

Meanwhile, English lecturer used codeswitching to switch the topic, to transfer the necessary knowledge to the students for clarity and comprehension, to build solidarity and intimate relations with the students, and may persuade or motivate students to be closer to the world of English. These motivational functions are similar to conclusion drawn by Wardhaugh (2002) and Gross (2002) that the speakers use code switching and mixing to build solidarity with listeners, choice of topic, negotiate position of power through their linguistic choices, and perceive social and cultural distance.

What it can be inferred from the above phenomenon is that English language teaching as part of language education in State Institute for Islamic Studies 'Imam Bonjol' Padang has to maintain several principles of using code mixing and switching dealing with goals and method of teaching:

- English lecturer should provide an understanding that the use of code-mixing and switching in the EFL teaching are to recognize the culture, social, and communicative validity of the mixing of two traditionally linguistic codes.

- English lecturer should introduce bilingual education in their EFL teaching.

\section{CONCLUSION}

With regard to the finding, Code mixing and switching help both lecturers and students to identify the relationship among language, culture, and education. In the context of cross cultural communication, as in the case of EFL learning in undergraduate program of English at Tarbiyah Faculty Imam Bonjol Padang, whose main purpose is to uphold the EFL teaching, the use of English in every-life interaction poses significant blocks. In other words, English could infiltrate in such a freezing atmosphere and provides smooth in touch with other local languages. The case of language contacts lead us to predict that borrowing, code-crossing, diglossia, and language shift will emerge in this institution.

The phenomena indicates that the strategy may be transmitted to the education is that teachers must be able to activate students' attributes or repertoires of knowledge and cultures to reach the goals of teaching. A large quantity of materials presented to the students is contra-productive to their cognitive development and yet, teachers have to convince students why they are studying it. 
Based on the analysis of data obtained from the participants in this study, the results reveal that tag-switching, intra-sentential, intersentential, and intra-word were commonly used in EFL teaching of cross cultural communication. This finding indicates that code-switching and mixing are still favored EFL teaching. In other words, they still play a particular role to help certain learners' or students' interlanguage develop and to help the teachers themselves to help explain in order to make their learners or students understand. This is an interesting phenomenon indicating that the use of first language (Indonesian) or native language (Bataknese, Minangkabaunese, and Javanese), and foreign language (Arabic and English) can never be avoided as along as the teaching of English as a target language is set in non-native countries.

As code mixing and switching signals motivational reasons in EFL teaching of cross cultural contact, language teachers should promote students identity especially related to language behavior, attitudes, and acknowledgment. Basically, students are human beings, zoon politicon, who need to interact in the most respectful manners, and therefore, language teachers need to color their performance with a little humanism. A language teacher also needs to realize the reason why God created human being in different races, colors, and language as well.

\section{REFERENCES}

Ayeomoni, M.O. (2006). Code-switching and Code-mixing: Style of Language Use in Childhood in Yoruba Speech Community. Nordic Journal of African Studies 15 (1): 90-99. Obafemi Awolowo University.

Appel, R. \& Mysken, P. (1987). Language Contact and Bilingualism. London: Edward Arnold.

Auer, P. (1998). Code-Switching in Conversation: Language, Interaction and identity. London: Routledge.
Butzkamm, W. (1998). Codeswitching in a bilingual history lesson: The mother tongue as a conversational lubricant. International Journal of Bilingual Education and Bilingualism 1 (2), 81-99

Cook, V. (2002). Portraits of the L2 user. Clevedon: Multilingual Matters.

Dardjowidjojo, S. (2000). English Teaching in Indonesia. EA Journal, 18 (1), 22-23.

Dardjowidjojo, S. (2003). The Role of English in Indonesia: A Dillema. In K.E. Sukamto (Ed.), Rampai Bahasa, Pendidikan, dan Budaya: Kumpulan Esai Soenjono Dardjowidjojo, 41-41. Jakarta: Yayasan Obor Indonesia.

David C.S. (2008). Understanding mixed code and classroom code-switching: myths and realities. New Horizons Journal. Vol. 5, No. 6, pp. 75-87.

Camilleri, A. (1996). Language values and identities: Codeswitching in secondary classroom in Malta. Linguistics and education 8, 85-103

Edstrom, A. (2006). Li Use in the L2 classroom: One teacher's self-evaluation. The Canadian Modern Language Review 62 (2), 275-292.

Elridge, J. (1996). Codeswitching in Turkish secondary school. English Language Teaching (ELT) Journal 50 (4), 303-311.

Gross, S. (2000). Intentionality and the markedness model in literary codeswitching. Journal of Pragmatics 32 (1): 1283-1303.

Gumperz, J. (1982). Discourse strategies. London: Cambridge University Press.

Hornberger, Nancy H. \& Sandra, L. M. (2010). Sociolinguistics and Language Education. London: St. Nicholas House, 31-34 High Street, Bristol BSI 2AW.

Kamisah, A \& Misysna, S.H. (2011). Codeswitching and code-mixing of English and bahasa Malaysia in Content-Based Classrooms: Frequency and Attitudes. The Linguistics Journal5(1): 220-247. 
Kamwangamalu, NM. Multilingualism and Codeswitching in Education. In Hornberger, Nancy H. and Sandra Lee Mckay. (2010). Sociolinguistics and Language Education. London: St. Nicholas House, 31-34 High Street, Bristol BSI 2AW. p. 116.

Moodley, V. (2003). Language attitudes and codeswitching behavior of faciliotators and learners in language, literacy and communbication senior phase outcomesbased education classrooms. Unpublished $\mathrm{PhD}$ thesis, University of Natal.

Muysken, P. (2000). Bilingual Speech: A Typology of Code-mixing. Cambridge: Cambridge University Press.

Nur, C. (2003). English Language Teaching in Indonesia: Changing Policies and Practices: In Kam, H.W., and Wong, R (eds.). English Language Teaching in East Asia Today: Changing Policies and Practices. Singapore: Times Academic Press.

Pagano, A.E. (2010). Code-switching: A Korean case study. Griffith Working Papers in Pragmatics and Intercultural Communication 3 (1): 22-38

Peires, M. (1994). Codeswitching as an aid to L2 learning: Shoutern African Journal of Applied Language Studies, 3 (1), 14-22.

Poplack, S. (1980). Sometimes I'll start in Spanish y termino en espanol: Towards a typology of code-switching. Journal of Linguistics 18 (2): 581-618.

Poplack, S. and Meechan, M. (1995). Patterns of language mixture: Nominal Structure in Wolof-French and Fongbe-French bilingual discourse. In L Milroy and $\mathrm{P}$ Muysken (eds) One Speaker, Two languages: Cross disciplinary Perspectives on Codeswitching (pp. 199232). Cambridge University Press

Rubdy, R. (2007). Singlish in the school: An Empediment or a resource? Journal of Multilingual and Multicultural Development 28 (4), 308-317.
Savignon, S. J. (2002). Sociocultural strategies for a dialogue of cultures. The Modern Language Journal 86: 508 $\square 524$.

Semiun, A. (2009). The Use of English as a Medium of Instruction by Senior High School EFL Teachers in NTT. (Dissertation). Malang: Universitas Negeri Malang.

Susanto, H.D. (2008). Code Switching in Indonesian Islamic Religious Discourse A Sociolinguistic Perspective. Malang: UIN-Malang Press.

Unamuno, V. (2008). Multilingual switch in peer classroom interaction. Linguistics and Education 19: $1 \square 19$.

Yuwono, G. (2005). English language teaching in decentralised Indonesia: Voices from the less privileged schools. Retrieved on April 2012 in http://www.are.edu.au/05pap/yuw05050. pdf.

Wardhaugh, R. (2002). An Introduction to Linguistics. ( $4^{\text {th }}$ Ed). Meiden Mass: Blackwell Publishers.

Zainil. (2005). Motivating the reluctant language learner. Padati-Web Journal. 2 (4): 1-12. 